\title{
1. Introduction: globalizing welfare - an evolving Asian-European dialogue
}

\author{
Stein Kuhnle, Per Selle and Sven E.O. Hort
}

\section{EXPANSION OF WELFARE STATE RESEARCH}

The welfare state is essentially a European invention (Flora 1986-87, p. xii) and it has over the last 70 years 'experienced its greatest proliferation and expansion in north-western Europe' (Castles et al. 2010). The World Economic Forum had, surprisingly, 'The Nordic Way' as one of the major topics for discussion at its annual meeting in Davos in 2011, and a couple of years later the cover of the liberal weekly magazine The Economist conveyed the message: 'The next supermodel: why the world should look at the Nordic countries' (The Economist 2013), which was even more surprising given its traditionally critical view on comprehensive, expensive welfare states.

Studies of the development of welfare states, both single-nation and comparative studies, have until recent decades been dominated by Western, particularly European, scholars. Welfare state research has, however, expanded greatly since the 1990s. Social and welfare policy has become a truly global field of study. The growing global academic and political attention to this field of research can be regarded as a result of rapidly broadening international epistemic communities in the social sciences, a greater concern with social, economic and gender inequalities within and across nations, and as a result of an expansion of social and welfare policies in more and more countries around the globe. Formulated at the time of emerging pioneering European welfare states towards the end of the nineteenth century, Adolph Wagner's 'law', on the expectation that far-reaching changes in economy and society would lead to more state intervention and rising public expenditure, has proved to be an apt forecast of global developments (Wagner 1893). 
But, as documented through extensive comparative welfare state research over the last 50 years (for example, Leibfried and Mau 2008; Castles et al. 2010; Greve 2018; Izuhara 2013; Aspalter 2017), welfare states come in different shapes and sizes. Given varieties of historical economic, social and political prerequisites and cultural contexts, there are many definitions of welfare, different justifications for state action and different roads to welfare. The form and degree of state responsibility for the social security, welfare and well-being of citizens vary, resulting in different types - or 'models' - of welfare states, and different paths of development (Arts and Gelissen 2010; Esping-Andersen 1990; Takegawa 2013). Welfare states vary across time and space as to the role of the state in terms of public spending for welfare, organization, financing and scope of cash benefits and provision of services, eligibility criteria and generosity of social programmes, and as to the interaction between the state, local communities, civil society and the market.

This book reflects the growing academic and political interest in global social policy and 'globalizing welfare'. A global welfare state dialogue has been under way during the last 20-plus years, and often based in large-scale projects on policy developments and data collections which concentrate on different parts of the world or in some cases aim at covering the world as a whole (for example, Deacon et al. 1997; Barrientos 2013; Leisering 2019; World Bank Group 2015; Yi 2017; Social Assistance Explorer n.d.; OECD 2018; MISSOC 2018; Global Dynamics of Social Policy ${ }^{1}$ ). Concomitantly, a number of academic journals have been established over the last 30 years to cover and develop regional and global dimensions of social policy, such as: Global Social Policy (2000), Journal of International and Comparative Social Policy (2013, originally established in 1984 as Journal of International and Comparative Social Welfare), Journal of European Social Policy (1990), Journal of Asian Public Policy (2008), Asian Social Work and Policy Review (2006). These, and other, journals can be considered helpful, even necessary, tools for advancing comparative welfare research and global social policy dialogues.

\section{DEVELOPING AN ASIAN-EUROPEAN DIALOGUE}

Japan was the first non-Western country ${ }^{2}$ to introduce social insurance legislation, with early laws on accident insurance (1911) and sickness insurance (1922). The idea and practice of varieties of social security schemes spread from Europe or 'the West' to other regions of the world after World War I and were actively triggered by the International Labour 
Organization (ILO) which was established in 1919 as part of the Treaty of Versailles that ended World War I. The major expansion of the European welfare states took place during the first thirty-year period after World War II, also called 'the Golden Age of the welfare state' (Pierson 1991; Esping-Andersen 1996). Across Europe, with different parties in power, there was broad consensus to pursue policies that promoted high employment and relatively high taxation to finance welfare state expansion. Social security, health and education programmes were expanded, the principle of universalism strengthened, cash benefits raised, and scope and quality of services improved. Economic growth and expansion of state responsibility for welfare grew hand-in-hand.

However, challenges of sustainability of advanced European welfare states are plenty. Since the 1970s, economic, political and demographic changes, and global financial developments and crises, have induced continuous reform activity in most developed countries aimed at curbing a future rise of social expenditures. Austerity, retrenchment, crisis and dismantlement became familiar concepts in welfare state research (Pierson 1994), but have been contested by alternative concepts of reconstruction, survival and resilience of welfare states (Leibfried and Mau 2008; Pierson 1996; Kuhnle 2000). Established entitlements and social rights in the context of ageing European societies have resulted in continuously high and relatively stable levels of social expenditure as a proportion of the gross domestic product (OECD Social Expenditure Database), with levels for the most part between 20 and 30 per cent. Persistently high levels of social expenditures are also a consequence of expansion of family policies in many countries, partly as responses to changes in the labour market and the changing role of women (and men) and subsequent demands for policies to reconcile work and life.

Towards the end of the twentieth century it was thought, with reference to the four 'tigers' (Hong Kong, Singapore, Taiwan and South Korea), that 'growth without welfare' was possible (Hort and Kuhnle 2000), although social policy legislation did accompany economic growth in Japan, the early example of Asian high-growth economies. The World Bank report on The East Asian Economic Miracle in 1993 made no mention of social policy developments in the area. But the currency and stock market crisis which hit East and South-East Asia in the summer of 1997 changed the frame of attention and the discourse. Expansion rather than dismantlement of state welfare responsibility has generally been the answer to the financial crisis, exemplified by developments in China, South Korea and Japan, as this book illustrates. Benefit levels are often low, however, and as is shown in Chapter 2, it is not easy to move from a developmental model towards a more universal welfare state model. 
Nevertheless, 'growth with welfare' can be observed in many growing Asian economies (OECD 2014; Abrahamson 2017).

Economically developed East Asian countries face many of the same welfare challenges as the more comprehensive and expensive European welfare states. Common challenges concern ageing of the population; migration; changes in the labour market; changes in the role of the family; changing relations between government, market and non-profit organizations; and social, economic and gender inequality. Attention to welfare issues and to the role of the state and state-market-non-profit organizations relations has increased in recent years. Displacement of relations in the state-market-non-profit organizations nexus in both East Asia and Northern Europe are analysed and discussed in several chapters (for example, Chapters 4, 8, 14 and 15).

Faced with new challenges of economic and social change, opinions differ in both Europe and Asia as to how comprehensive state welfare responsibility should be, what level of social security should be guaranteed, how welfare should be organized and financed, and how much equality is desirable. For example, in the West, governments of the Nordic countries and Germany have chosen different paths from those of the United States (US) and the United Kingdom. The emphasis on public and universal welfare responsibility and provision is comparatively stronger in the Nordic countries and in continental Europe, although recent social policy reforms in several Nordic countries also imply reduced benefits and stricter eligibility, for example, for unemployment benefits and social assistance, and a stronger future connection between labour market participation and social rights. In East Asia, policy responses to social challenges differ, as shown in the chapters in Part I, between Hong Kong, China, South Korea and Japan, where Hong Kong appears most reluctant to expand social policies and move towards universalism, while China currently appears to be the most active of the four.

The differential developmental experiences and current common challenges in established European welfare states and in countries of one of the most dynamic regions of economic development in the world, the emerging East Asian welfare states, invite both historical comparisons and comparisons of problems and policy responses at the present time. To what extent, and in what way, do East Asian nations look to the experiences and lessons of Northern Europe? To what extent are they innovative in social policies? How do highly developed Northern European welfare states meet current social challenges? Which issues are global, that is, of relevance across different economic, political and cultural contexts? How do countries in the two different regions of the 
world respond to the challenges of migration (from abroad, or within the country as in China)? In what way do new across- and/or within-nation migration patterns represent a challenge for the future of the welfare state? As discussed in Chapter 19, right-wing populist, anti-globalization parties have emerged all over Europe in recent years, including in the North. Such parties are not necessarily questioning the welfare state as such, but want to keep the welfare state for 'themselves' when faced with large-scale immigration. The Chinese one-party state experiences largescale internal migration and may face similar challenges as democratic European states regarding tendencies towards 'welfare chauvinism', but in this case possibly reflecting unequal developments and standards of living between regions, provinces and rural and urban populations.

Although political and cultural contexts differ, we think that common elements in challenges facing mature European welfare states and rapidly developing East Asian countries motivate the initiation of a dialogue and joint exploration of similarities and differences in policy responses and their effects. We think that the time has come for an Asian-European dialogue on mutual social policy learning. Perceptions of the problems faced may differ, and views on desirable policy solutions will certainly differ. The (five) Nordic countries are small, counting a total of 25 million people, and have received international attention disproportionate to their size, but nations big and small can probably draw lessons from their experience. Meanwhile, European welfare states can learn from current policy developments in East Asian nations whose political and economic role in the world is of increasing importance.

China's social policy choices can potentially have a significant impact regionally as well as globally, given the country's increasing presence on the global economic and political scene and its ascendance to the rank of the second-largest economy in the world. China, and East Asian countries in general, can come to play a greater role in international political forums and social policy epistemic communities in which scholars and practitioners representing different welfare model traditions and experiences meet. Welfare models, for political, cultural and other reasons, are not likely to converge in a short-term perspective, and this may not be an aim as such, but ideas and policy learning will diffuse globally more easily than before, and are likely to have an impact upon social policy thinking and reforms in both regions and across the continents.

The book has several aims. One general aim is to increase the substantial up-to-date knowledge about developments in the two regions of North-East Asia and North-Western Europe and at the same time to highlight that not only the economy has been globalizing, but also the welfare state and policies for social protection and welfare. It is safe to 
say that the welfare state has turned out to be more resilient than expected since the neo-liberal ideological wave swept the world from the early 1980s, manifested by the Thatcher and Reagan years in power, but also by the Organisation for Economic Co-operation and Development (OECD), which in 1981 published the book The Welfare State in Crisis. The 'race to the bottom' thesis can be challenged (Berry et al. 2003; The Economist 2016). One paradox is that the strongest attack on the extensive social policy role of the state came in some of the least comprehensive modern Western welfare states, not in the most comprehensive welfare states in Northern and Continental Europe. Neoliberalism was - and is - not 'the only game in town'. Obviously, variations of economic globalization, as well as variations in the political and cultural dimensions of globalization, must be taken into account to understand the development of social policy and welfare states (Palier and Sykes 2001).

The Northern European countries were welfare state pioneers and today represent some of the most comprehensive welfare states in the world, at the same time as their economies generally are in comparatively good shape. The North-East Asian countries had a later economic take-off, and later development of social policies, but have experienced a much more rapid economic growth, and are currently faced with the challenges of consolidating and expanding state responsibility for the social protection and welfare of their citizens. Both Part I, 'Developing East Asian Welfare States: Internal Forces and Outside Influences', and Part II, 'Developed North European Welfare States: State and Society in a Globalizing World', provide perspectives on current trends of policy development. A further aim of the book is to inspire more attention to policy learning perspectives. A final aim, covered in Part III, 'Global Issues and Perspectives', is to highlight important cross-cutting, critical global issues for the future development of welfare states, in particular growing social and economic inequality, persistent gender inequality, the rise of authoritarian populism, and risks of more political and social instability in an increasingly globalized world.

\section{STRUCTURE OF THE BOOK}

The book brings together scholars within the field of comparative welfare state research and comparative studies of civil society and voluntary organizations and state-society relations from China, Hong Kong, Japan, South Korea, the United States, Germany, Belarus, Denmark, Finland, Norway and Sweden. Analyses - historical, current and future-oriented 
perspectives - and reflections on the normative foundations of welfare state construction and actual policy development are presented, as well as examples of reflections on the international exchange of ideas, knowledge and policy experiences.

The book is divided into three parts. In Part I, 'Developing East Asian Welfare States: Internal Forces and Outside Influences', Huck-ju Kwon (Chapter 2) analyses the social policy development in South Korea and shows that policies have become more inclusive, but that the transition from the developmental to the universal welfare state has proved to be very difficult. The development of social policies in China is described and analysed by Yuan Ren (Chapter 3) and by Yi Pan and Ziyu Wang (Chapter 4). Yuan Ren makes comparative references to the Nordic welfare experience and reflects on the compatibility with the experience of China; while Yi Pan and Ziyu Wang address four turning points in the development of the Chinese welfare system and explore the adoption of the principle of 'moderate universalism'. Raymond Chan (Chapter 5) contrasts the welfare models of the Nordic countries and Hong Kong. He argues that although the welfare system has experienced some expansion in Hong Kong, the recent economic crisis has not changed traditional neo-liberal and conservative orientations. Developments in Japan, the first 'economic miracle' in East Asia, are surveyed through three chapters. Masato Kamikubo (Chapter 6) shows that welfarist policies were on the agenda of the government of the Democratic Party of Japan in 2009, but that the influence of less welfare-oriented conservative supporters within the Liberal Democratic Party after it returned to power in 2012 has increased. Attending to the common challenge of ageing societies, Yoko Otsuka and Lingyan Chen (Chapter 7) make a comparison across countries and welfare regimes of the role of women as caregivers. They study the relationships between care workers and family caregivers in Denmark, Japan and China and conclude that the role of women remains ambiguous, straddled between the public and private spheres, regardless of whether the country is a developed or a developing welfare state. Masanari Sakurai (Chapter 8) analyses whether the role of non-profit organizations (NPOs) in the welfare field in Japan has changed after a law to promote specified non-profit activities was enacted in the 1990s. He finds that NPOs have generally succeeded in preserving their philanthropic values, but that some types of non-profit corporations have a strong commercialization tendency.

In Part II, 'Developed North European Welfare States: State and Society in a Globalizing World', focus is shifted to the Nordic countries, and includes an excursion to Germany. Pauli Kettunen (Chapter 9) explains the historical closeness of the concepts of state and society in 
the Nordic context, and argues that the notion of the state as a society preceded the formation of the welfare state and thus contributed to the legitimacy of state interventions. The attempt by welfare state critics to introduce the concept of 'welfare society' to signify a political alternative has been futile. Based on broad empirical analyses of data over several decades, Jørgen Goul Andersen (Chapter 10) assesses the challenge of globalization for the sustainability of the Nordic welfare state. His conclusion is that globalization overall leads to more opportunities for than threats to the welfare state, but that integration of low-skilled immigrant refugees in the workforce and the sustainability of high minimum wages remain significant challenges. Åsa Lundqvist (Chapter 11) explores the development - and challenges - of the normative foundations of Nordic family and gender equality policies since the 1960s, with emphasis on the Swedish case. She identifies four different phases and finds both continuities and changes in the normative foundations, and concludes that the main challenge today is how to simultaneously develop the guiding principles of the Nordic welfare states, universalism and egalitarianism, and manage diversity and various forms of discriminatory practices related to gender, ethnicity, sexuality and religion. Based on extensive analyses of public documents and debates, Klaus Petersen (Chapter 12) shows how changing public day care policies for children in Denmark since the 1950s have triggered the classical political questions: who gets, who organizes, who pays? The chapter illustrates how the debate on day care was closely related to shifting debates about gender roles, the autonomy of families, gender equality, responsibility for and the interests of children. Rune Ervik, Nanna Kildal, Stein Kuhnle and Tord Skogedal Lindén (Chapter 13) give a historical account of the Norwegian welfare state by delineating the evolvement of the public pension system and the role of normative ideas of justice and fairness in that process. Normative principles of universalism, reciprocity and targeting have been important in all phases, but their relative importance has varied. The most recent pension reform of 2011 weakens the universal character of the pension system and moves it towards reciprocity. Helmut Anheier (Chapter 14) provides an assessment of the future of civil society in Germany based on the modernization of the welfare state through private-public partnerships; the role of community in an increasingly secular society; the role of transparency and accountability in the political-administrative sphere; and openness towards social innovation. He argues that the more spheres of civic freedom are based on an individual right to bear responsibility for oneself and for others, the less contradictory and conflictual the future of civil society is expected to be. In Norway the voluntary sector played a 
different and crucial role in the early development of the welfare state, but a radical change in the relationship between this sector and the state can now be observed, according to Per Selle and Kristin Strømsnes (Chapter 15). This change occurs as the market sector has gained an important role in the new quasi-markets within health and social services. They analyse the connection between the entry of market actors and the weakness of the service role of the institution-based voluntary sector in the present welfare state. Chapters 14 and 15 indicate that the current Norwegian development in the role of the voluntary sector stands in contrast to that of Germany.

Part III, 'Global Issues and Perspectives', addresses topics of global relevance for the future of the welfare state. Gender relations remain central to social politics and social policies, as spelled out in contributions to Part I and II. Marie Laperrière and Ann Shola Orloff (Chapter 16) discuss the ways in which welfare states have responded to the challenge of persistent patterns of gender inequality in wages and opportunities. Although gender awareness has become the norm in much welfare state scholarship, issues of power are often occluded. The authors argue that one has to build on the long tradition of feminist scholarship that has emphasized the workings of power inside welfare states to better understand the potential of states to promote gender equality. Sven Hort and Nikolay Zakharov (Chapter 17) pay attention to developments in Belarus, a rarely exposed case of the welfare state in the post-Soviet world. Belarus has only slowly left the Soviet legacies behind. The significance of this case study has increased at a time when the authoritarian-populist tide is on the rise in both Western and CentralEastern Europe, and it can serve as an example of the general possibility of the emergence of authoritarian-populist welfare states. Claus Offe (Chapter 18) discusses the framing of inequality and related policy processes. Codes used in such framing are, for example, deserving versus undeserving poor, equality of opportunity versus equality of outcomes, egalitarian distributive justice versus allocative efficiency, consumption versus investment, public versus private responsibility, 'desert' versus rights versus compassion, autonomy versus dependency, generosity versus affordability, rewards versus incentives, and social integration versus system integration. The chapter offers ideas and speculations concerning patterns of change that these frames and codes have been subject to in the OECD world since World War II. Finally, Stephan Leibfried, Kerstin Martens and Uwe Schimank (Chapter 19) take a look at the recent phenomenon of right-wing populism as a major political force in most Western countries, and how it can be understood within an analytical triangle of inequalities, the welfare state and democracy. They reject both 
the interpretation that right-wing populism was articulated by left-behind members of the lower classes and the assumption that the culturally deprived tend towards right-wing populism. Both interpretations are found to oversimplify the 'entangled inequalities' from which right-wing populism originates. Further comparative studies of the interplay of inequalities, welfare policies and democracy are needed.

\section{LOOKING AHEAD: THE UNEVEN COMING OF THE WELFARE STATE IN THE TWENTY-FIRST CENTURY}

The universal grammars of welfare state scholarship constantly have to be scrutinized and rethought. There are no longer three 'worlds' of advanced welfare capitalism. Models or regime types can probably still be distinguished, but there is no uniformity in complexity. Hence, there is no contemporary 'single modernity' despite globalization in its various dimensions. Looking back and looking forward, there is a need for caution when contemporaneity is in flux. The relationship between distribution of pre-tax income and wealth, and post-tax redistribution of cash and in-kind benefits, and between social rights and social obligations, has to be reconfigured along the route in comparative welfare research. The institutions of social security - the welfare state - is one such pathway. The archetypical welfare state is a central aspect of modern human community. However, in rhetoric it is often blurred into private-public obscurity, and not always clear-cut in its circumscriptions or definitions.

Three decades ago, the triumph of democracy also signalled the collapse of the Soviet-type totalitarian welfare state and the type of society characterized by 'equality in poverty' that dominated a third of humanity. The directions of the paths from 1989 - the fall of the Berlin Wall, and the end to conceptualizations of both the Second and the Third World - are in no sense unequivocal (Fukuyama 2014). While global poverty has diminished considerably within most nation-states, whether middle-income or advanced, inequalities have grown dramatically (Milanovic 2016). Simultaneously, social security institutions - the key element of the welfare state - have blossomed in various parts of the world under the guidance of international institutions and organizations, and under pressure from constituencies of different sorts (see, for example, Lavinas 2017; Kannan and Breman 2013). Thus, the strength of some states (including state-like organizational endeavours such as the European Union) at the expense of others in the creation of human welfare has to be reconsidered. So has the weakness of some voluntary 
associations - political parties and trade unions in particular in Western democracies - at the cost of other types of civil society phenomena: (social) media and ethno-gendered non-governmental organizations most spectacularly.

Two decades into the twenty-first century, warfare and welfare as constituent contrasts of the present world - human modernity and its shadows of contemporary inequality and poverty - again come to the fore. The role of social policy and welfare states as crucial elements in a global human civilizing process are key themes in the chapters included in this volume. In a book focusing on the exchange of ideas and practices between East Asia and North-Western Europe, it is more than conventionally necessary to emphasize that geography and geopolitics matter, and that different regional pre-histories are core in understanding the different paths. Viewed in the West as a time of self-confident progress and the development of a variety of welfare states, the post-World War II epoch was experienced by many Asians as a continuation of a centurylong catastrophe dating back to the Opium and Pacific wars. From the ruins of empire, Japan became the first Asian welfare state, but the remaking of East Asia - the most populous part of the present world has only recently begun, despite a true beginning in the 1870s (Weiss 2016; Wang 2005).

From the start, contemporary globalization was often equated with neo-liberalism and, in comparative welfare state research, associated with downscaling of welfare state obligations and social rights. Globalization of the Reagan and Thatcher era saw the rise of a new-old critique of ever-growing social programmes and welfare policies (see, for example, OECD 1981). Structural adjustment programmes in less developed countries often took the shape of cutbacks in health, education and welfare, and the international organizations behind what were on the surface well-intended anti-corruption advice and practice gained a bad reputation. More recently, research on tackling corruption has indicated its importance for diminishing human inequality and well-establishing well-functioning social security institutions, making social solidarity and trust in public institutions possible (Rothstein and Varraich 2017).

However, dismantling the advanced welfare state was an exclusively Western story, and limited to a few countries, including the archetypical one: Sweden (Hort et al. forthcoming; Hort 2014). The welfare state survived. Simultaneously, Hort and Kuhnle (2000) could present an analysis of the emergence in East and South-East Asia of an institutional set-up close to the advanced welfare states of the "three worlds of welfare capitalism' (Esping-Andersen 1990). From Japan to South Korea and the other 'small tiger economies' (Hong Kong, Singapore and Taiwan), as 
well as a 'second generation' of such economies (Thailand, Malaysia, Vietnam) in this region, showed a significant increase in systems of social protection and social welfare. At that time, the big question mark was over the People's Republic of China. Two decades later we know a lot more about the development of social welfare in China, but there is still more to learn, as Chapters 3 and 4 of this volume bear witness. China, however, is not alone: large entities such as India and Indonesia have also enlarged their systems of social protection, in particular for the elderly and in the field of health (Aspalter 2017).

However, state welfare is controversial, and the term does to some ears sound both intrusive and overprotective - 'get the government out of your pockets' as an old North American saying goes; while the welfare state in at least some parts of the world, perhaps particularly in the Far North, is seen as empowering and securing human beings. The combination of these two words, 'state' and 'welfare', as well as arousing feelings of approval, has caused alarm, or fear, or even hatred, as evidenced, for example, in the US discourse on 'Obamacare' and health insurance for all.

Searching for the future of social welfare, there are advances as well as retreats. Hence, this book is about an evolving global dialogue, here exemplified by an emerging East Asian-Northern European dialogue, that has followed in the steps of the establishment of this combination of welfare and state, whether in organized international cooperation, political decision-making, symbolic politics or social research. Yet most of these currents are still national in both content and form, though learning processes are in many cases transnational.

\section{NOTES}

1. A huge research programme on Global Dynamics of Social Policy, directed by Herbert Obinger, started in 2018 and is an association of eight research institutions at the University of Bremen, cooperating with Jacobs University Bremen, the University of Duisburg-Essen and the University of Cologne.

2. If we regard Australia and New Zealand as 'Western countries'.

\section{REFERENCES}

Abrahamson, P. (2017), 'Future welfare - an uneven race to the top and/or a polarized world?', in C. Aspalter (ed.), The Routledge International Handbook to Welfare State Systems, London: Routledge, pp. 41-70. 
Arts, W.A. and J. Gelissen (2010), 'Models of the welfare state', in F.G. Castles, S. Leibfried, J. Lewis, H. Obinger and C. Pierson (eds), The Oxford Handbook of the Welfare State, Oxford: Oxford University Press, pp. 569-85.

Aspalter, C. (ed.) (2017), The Routledge International Handbook to Welfare State Systems, London: Routledge.

Barrientos, A. (2013), Social Assistance in Developing Countries, Cambridge: Cambridge University Press.

Berry, W.D., R.C. Fording and R.L. Hanson (2003), 'Reassessing the "race to the bottom" in state welfare policy', Journal of Politics, 65 (2), 327-49.

Castles, F.G., S. Leibfried, J. Lewis, H. Obinger and C. Pierson (eds) (2010), The Oxford Handbook of the Welfare State, Oxford: Oxford University Press.

Deacon, B., M. Hulse and P. Stubbs (1997), Global Social Policy: International Organizations and the Future of Welfare, London: SAGE.

The Economist (2013), 'The next supermodel: why the world should look at the Nordic countries', Cover, 2 February.

The Economist (2016), 'Racing to the bottom', 15 March.

Esping-Andersen, G. (1990), The Three Worlds of Welfare Capitalism, Cambridge: Polity Press.

Esping-Andersen, G. (ed.) (1996), Welfare States in Transition, London: SAGE.

Flora, P. (ed.) (1986-87), Growth to Limits. The Western European Welfare States since World War II, Vol. 1, Sweden, Norway, Finland, Denmark (1986); Vol. 2, Germany, United Kingdom, Ireland, Italy (1986); Vol. 4, Appendix: Synopses, Bibliographies (1987), Berlin: Walter de Gruyter.

Fukuyama, F. (2014), Political Order and Political Decay: From the Industrial Revolution to the Present Day, New York: Farrar, Straus \& Giroux.

Greve, B. (ed.) (2018), The Routledge Handbook of the Welfare State, 2nd edition, London: Routledge.

Hort, S.E.O. (2014), Social Policy, Welfare State, and Civil Society in Sweden, Vol. 11, The Lost World of Social Democracy 1988-2015, Lund: Arkiv.

Hort, S.E.O. and S. Kuhnle (2000), 'The coming of East and South-East Asian welfare states', Journal of European Social Policy, 10 (2), 162-84.

Hort, S.E.O., L. Kings and Z. Kravchenko (forthcoming), 'The Swedish welfare system: the neoliberal turn and the most recent struggles over de-centralized top-down re-regulation', in K. Schubert, S. Blum and J. Kuhlmann (eds), Routledge Handbook of European Welfare Systems, London: Routledge.

Izuhara, M. (ed.) (2013), Handbook on East Asian Social Policy, Cheltenham, UK and Northampton, MA, USA: Edward Elgar Publishing.

Kannan, K.P. and J. Breman (eds) (2013), The Long Road to Social Security: Assessing the Implementation of Social Security Initiatives for the Working Poor in India, New Delhi: Oxford University Press.

Kuhnle, S. (ed.) (2000), Survival of the European Welfare State, London: Routledge.

Lavinas, L. (2017), 'The untold battlefields against inequality in Latin America', in G. Olofsson and S. Hort (eds), Class, Sex and Revolutions, Lund: Arkiv, pp. $225-43$.

Leibfried, S. and S. Mau (eds) (2008), Welfare States: Construction, Deconstruction, Reconstruction, Vol. I, Analytical Approaches; Vol. II, Varieties and 
Transformations; Vol. III, Legitimation, Achievements and Integration, Cheltenham, UK and Northampton, MA, USA: Edward Elgar Publishing.

Leisering, L. (2019), The Global Rise of Social Cash Transfer: How States and International Organizations Constructed a New Instrument for Combating Poverty, Oxford: Oxford University Press.

Milanovic, B. (2016), Global Inequality: A New Approach for the Age of Globalization, Cambridge, MA: Harvard University Press.

MISSOC database (2018), 'Mutual information system on social protection, European Union', accessed at https://www.missoc.org/.

OECD (1981), The Welfare State in Crisis, Paris: OECD.

OECD (2014), Asia-Pacific at a Glance, Paris: OECD.

OECD (2018), OECD Social Expenditure Database (SOCX), accessed at http:// www.oecd.org/social/expenditure.htm.

Palier, B. and R. Sykes (2001), 'Challenges and change: issues and perspectives in the analysis of globalization and the European welfare states', in R. Sykes, B. Palier and P.M. Prior (eds), Globalization and European Welfare States, Basingstoke: Palgrave, pp. 1-16.

Pierson, C. (1991), Beyond the Welfare State? The New Political Economy of the Welfare State, Cambridge: Polity.

Pierson, P. (1994), Dismantling the Welfare State? Reagan, Thatcher and the Policy of Retrenchment, Cambridge: Cambridge University Press.

Pierson, P. (1996), 'The new politics of the welfare state', World Politics, 40 (2), 143-79.

Rothstein, B. and A. Varraich (2017), Making Sense of Corruption, Cambridge: Cambridge University Press.

Social Assistance Explorer (n.d.), accessed at http://www.social-assistance. manchester.ac.uk/.

Takegawa, S. (2013), 'Between Western Europe and East Asia: development of social policy in Japan', in M. Izuhara (ed.), Handbook on East Asian Social Policy, Cheltenham, UK and Northampton, MA, USA: Edward Elgar Publishing, pp. 41-64.

Wagner, A. (1893), Grundlegung der politischen Õkonomie, Leipzig: Winter.

Wang, C. (2005), One China, Many Paths, London: Verso.

Weiss, A. (2016), Asiaten in Europa - Begegnungen zwischen Asiaten und Europäern 1880-1914, Paderborn: Ferdinand Schöningh.

World Bank (1993), The East Asian Miracle: Economic Growth and Public Policy, Washington, DC: World Bank.

World Bank Group (2015), The State of Social Safety Nets 2015, Washington, DC: International Bank of Reconstruction and Development/World Bank.

Yi, I. (2017), Towards Universal Health Care in Emerging Economies: Opportunities and Challenges, Geneva: UNRISD. 